\title{
MANH $\bar{A} J$ MAJELIS TARJIH MUHAMMADIYAH DALAM TRANSFORMASI HUKUM ISLAM (FATWA)
}

\author{
Abdi Wijaya \\ Fakultas Syariah dan Hukum UIN Alauddin Makassar
}

\begin{abstract}
:
Muhammadiyah in issuing fatwas uses manhaj and varied approaches according to the substance of the problems that arise. Can not be denied, Muhammadiyah has contributed in the transformation of Islamic law in the form of fatwas related to problems that exist in society.
\end{abstract}

Keywords: Manhaj, Transformation, Fatwa

\section{A. PENDAHULUAN}

Ajaran Islam pada hakekatnya mencakup berbagai dimensi, baik dimensi teologi, spiritual, moral, sejarah, kebudayaan, politik, hukum, maupun ilmu pengetahuan. ${ }^{1}$ Tegasnya, bahwa Islam tidak hanya mengatur masalah ibadah ritual dalam hubungan vertikal dengan Tuhan saja, tetapi ia juga mengatur hubungan manusia dalam interaksi sosial kemasyarakatan. ${ }^{2}$

Keberadaan hukum Islam adalah untuk mengatur interaksi manusia dalam kehidupan sosial kemasyarakatan. Hukum Islam mempunyai dua fungsi, yaitu sebagai pengatur kehidupan masyarakat atau social control, dan sebagai pembentuk masyarakat atau social enginering. ${ }^{3}$

Di samping itu, hukum Islam mempunyai dua dimensi. Pertama, hukum Islam berdimensi iliyāh, karena ia diyakini sebagai sumber ajaran yang bersumber dari Tuhan yang Mahasuci, Maha Sempurna, dan Maha Benar. Dalam dimensi ini hukum Islam diyakini oleh umat Islam sebagai ajaran suri karena bersumber dari Yang Mahasuci dan sakralitasnya senantiasa dijaga. Dalam pengertian seperti ini, hukum Islam dipahami sebagai syariat yang cakupannya begitu luas, tidak hanya terbatas pada fikih dalam artian terminologi. Ia mencakup bidang keyakinan, amaliah dan akhlak. Kedua, hukum Islam berdimensi insāniyāh. Dalam dimensi ini, hukum Islam merupakan upaya manusia secara sungguh-sungguh untuk memahami ajaran yang dinilai suci tadi dengan melakukan dua pendekatan, yaitu pendekatan kebahasaan dan pendekatan maqāsìd. Dalam dimensi ini, hukum Islam dipahami sebagai produk pemikiran yang dilakukan dengan berbagai

\footnotetext{
${ }^{1}$ Harun Nasution, Islam Ditinjau dari Berbagai Aspeknya, Jilid I (Cet. V; Jakarta; UI Press, 1985), h. 4 .

${ }^{2}$ Yoseph Schachat, An Introduction to Ismaic Law (Oxford: Oxford University Press, 1964), h., 1.

3 Amir Syarifuddin, Meretas Ijtihad; Isi-Isu Penting Hukum Islam Kontemporer di Indonesiaa (Cet. I; Jakarta: Ciputat Press, 2002), h. 3.
} 
pendekatan yang dikenal dengan sebutan ijtihad. ${ }^{4}$ Dengan demikian, dari segi dalil atau sumber (formil) hukum Islam, ada yang berdimensi Ilahi dan ada yang berasal dari potensi insani. ${ }^{5}$

Dari uraian diatas, dapat dikemukakan bahwa pada satu sudut pandang, hukum Islam merupakan sesuatu yang tidak akan mungkin mengalami perubahan, karena berdasarkan wahyu Allah yang bersifat qadim. Setiap yang qadim, bersifat statis tidak berubah. Namun dari sudut pandang lain, hukum Islam tidak statis, tetapi mempunyai daya lentur yang dapat sejalan dengan sesuatu yang berubah dan bergarak. ${ }^{6}$ Hal ini sejalan dengan realitis bahwa secara sosiologis masyarakat selalu mengalami perubahan. Perubahan suatu masyarakat dapat mempengaruhi pola pikir dan tata nilai yang ada pada masyarakat itu. Semakin maju cara berpikir suatu masyarakat, akan semakin terbuka untuk menerima kemajuan ilmu pengetahun dan teknologi. Hal itu bagi umat Islam menimbulkan berbagai problem hukum Islam yang terkadang belum dikaji, dan bahkan belum terpikirkan oleh ulama sebelumnya.

Transformasi hukum Islam di Indonesiaa dilakukan melalui empat cara. Salah satu di antaranya adalah melalui proyeksi fatwa. ${ }^{7}$ Dalam kaitan ini, Muhammadiyah sebagai salah satu organisasi sosial keagamaan di Indoneias melakukan ijtihad untuk memberikan fatwa ${ }^{8}$ terhadap problematika hukum Islam yang terjadi dalam masyarakat. Fatwa hukum Islam di kalangan organisasi Muhammadiyah di percayakan kepada Majelis Tarjih dan Pengembangan Pemikiran Islam (MT-PPI) Muhammadiyah. ${ }^{9}$

\section{B. PEMBAHASAN}

\section{Manhāj Majelis Tarjih Muhammadiyah}

Dalam perspektif sejarah, dinamika pemikiran hukum Islam di Indonesia setidaknya menunjukkan satu fenomena trasformatif dan remedialis, walaupun masih tampak kuat nuansa paralelisme didalamnya. Mendasar pada sifat kesinambunagn dan perubahan, geliat pemikran ini telah mengalami, bukan saja tambal sulam, melainkan sudah seperti bola salju, terus menggelinding dan melaju merekontruksi berbagai type dan karakter baru. Karena itu, wajar bila taksonomi dan tipologi yang pernah ada dan mapan yakni moderenis dan tradisionalis, ${ }^{10}$ tidak relevan lagi untuk menggambarkan dan mengatakan harakah pemikiran itu.

${ }^{4}$ Juhaya S Praja, Dinamika Pemikran Hukum Islam, ”(Pengantar), Dalam Jaih Mubarak, Sejarah dan Perkembangan Hukum Islam (Cet. I; Bandung; PT. Remaja Rosdakarya, 2000), h. vii.

5 Juhaya S Praja, Filsafat Hukum Islam (Cet. I; Bandung; Piara, 1993), h. 77.

${ }^{6}$ Amir Syarifuddin, Meretas Ijtihad; Isi-Isu Penting Hukum Islam Kontemporer di Indonesiaa, h. $3-4$. h. 196 .

${ }^{7}$ Abdul Mannan, Reformasi Hukum Islam di Indonesiaa (Cet. I; PT. Raja Grafindo Persada, 2006),

${ }^{8}$ Fatwa adalah pendapat yang dikemukakan seorang mujtahid atau faqih sebagai jawaban yang diajukan peminta fatwa dalam suatu kasus yang sifatnya tidak mengikat. Abdul Azis Dahlan, Ensiklopedi Hukum Islam, Jilid I (Cet. V; PT. IchtiatrBaru Van Houve, 2001), h. 326.

${ }^{9}$ Jaih Mubarak, Metodologi Ijtihd Hukum Islam (Yogyakarta: UII Press, 2002), h. 181.

${ }^{10}$ Mahsun Fuad, Hukum Islam Indonesiaa dari Nalar Partisipatoris Hingga Emansipatoris (Cet. 1; Yogyakarta: Lkis, 2005), h. 1. 
Walaupun penyebutan moderenisme pemikiran Islam di Indonesiaa kepada Muhammadiyah ${ }^{11}$ tidak mutlak dalam konteks kekinian, namun Muhammadiyah menyerupakan organisasi sosial keagamaan Islam yang dijuluki sebagai gerakan Islam. Gerakan dakwah dan gerakan tajdid. ${ }^{12}$

Dalam kaitan di atas pada tahun 1968, Muhammadiyah sudah merasa perlu merumuskam apaya yang dinamakan dengan tajdid bahwa:

Perkataan tajdìd mempunyai dua makna, adalah dilihat dari sasarannya.

Pertama, pembaruan yang bermakna mengembalikan kepada yang aslinya, ialah apabila tajdid itu sasarannya masalah yang mempunyai sandaran, dasar, landasan, dan sumber yang tidak merubah. Kedua, berarti pembaruan yang bermakna moderenisasi, ialah apabila tajdidi itu sasarannya masalah yang tidak mempunyai sandaran, dasar, seperti metode, sistem, teknik, starategi, taktik dan lain-lain yang sebangsa dengan itu, ialah untuk disesuaikan dengan situasi dan kondisi/ruang dan waktu. ${ }^{13}$

Pada prinsipnya Muhammadiyah mengakui peranan akal dalam memahami Alquran dan hadis. Namun kata-kata yang dijiwai ajaran Islam memberi kesan bahwa akal cukup terbatas dalam menyelesaikan masalahmasalah yang muncul sekarang, dan akal juga terbatas dalam memahami Alquran dan hadis.

Dengan demikian, dalam Muhammadiyah fungsi akal tidak dominan dalam memecahkan persoalan-persoalan hukum Islam. Jelasnya, bahwa Muhammadiyah menegaskan kenisbian akal dalam memahami nas Alquran dan hadis . Namum kenisbian akal itu hanya terbatas dalam memahami masalah-masalah ibadah yang ketentuannya sudah di atur dalam nas .

Keputusan Majlis Tarjih dapat dikoreksi, asalkan disertai dalil atau petunjuk dalil yang lebih kuat. Namun, koreksi itu harus melalui keputusan Majelis Tarjih yang didasarkan kepada musyawarah, sesuai dengan ketentuan organisasi. Ini menunjukkan, bahwa keputusan Majlis Tarjih bukanlah yang paling benar tetapi disaat memutuskan dipandang paling mendekati kebenaran diantara dalil-dalil yang diperoleh saat itu. Konsekuensi logisnya, adalah keputusan Majlis Tarjih masih ada kemungkinan mengalami perubahan jika dikemudian hari ada dalil atau landasan yang dipandang lebih kuat. Hal itu telah terjadi beberapa kali. Misalnya, pernah diputuskan larangan memasang gambar KH. Ahmad Dahlan dikuatirkan warga Muhammadiyah akan mengkultuskan individualkannya. Namun, dengan pertimbangan beliau sebagai pendiri Muhammadiyah, dan dipandang perlu untuk memperkenalkan sosok KH.Ahmad Dahlan kepada generasi berikutnya, maka larangan itu kemudian dicabut, dan diperbolehkan memasang gambarnya ditempat-tempat

\footnotetext{
${ }^{11}$ Lihat Deliar Noer, Gerakan Islam Modern di Indonesiaa 1990-1942(Jakarta: LP3ES, 1982),h. 114. h. $48-49$.

${ }^{12}$ Mustafa Kamal, et al., Muhammadiyah Sebagai Gerakan Islam ( Yogyakarta: Persatuan, 1988),

${ }_{13}$ Djindar Tamimi, "Tajdid: Ideologi dan Chittah Perjuangan Muhammadiyah," Buletin Suara Muhammadiyah, No. 91, 16 September 1969, h. 3.
} 
pendidikan Muhammadiyah. Namun demikian, hal-hal yang menjurus ke arah kultus pribadi tetap menjadi perhatian yang kritis di Muhammadiyah. ${ }^{14}$

Di samping manhaj Tarjih Muhammadiyah juga membedakan urusan agama dan dunia. Di samping itu juga digunakan pendekatan ilmu pengetahuan (sains) dalam memahami persoalan keduniaan walaupun berkaitan dengan urusan ibadah. Misalnya, air yang dua kullah atau lebih, kurang dari satu meter kubik, dipandang suci menurut fiqh. Namun kenyataannya, ada surau atau mesjid yang air kolamnya sudah hijau, penuh dengan kuman, juga tetap dipandang suci. Padahal dari segi kesehatan justru berbahaya. Maka Majelis Tarjih memandang perlunya melakukan interpretasi tentang air bersih dan suci berdasarkan hasil penelitian.

Adapun metode ijtihad yang digunakan Majlis Tarjih meliputi:

a. Ijtihād bayānī, yaitu ijtihad terhadap nash yang mujmal, baik karena belum jelas makna lafaz yang dimaksud, maupun karena lafaz itu mengandung makna ganda, mengandung arti musytarak, ataupun karena pengertian lafaz dalam ungkapan yang konteksnya mempunyai arti yang (ta'arrud). Dalam hal yang terakhir digunakan jalan ijtihad dengan jalan Tarjih, apabila tidak dapat ditempuh dengan cara jama'tawfiq

b. Ijthād qiyāsì, yaitu menyeberangkan hukum yang telah ada nashnya kepada masalah baru yang belum ada hukumnya berdasarkan nash, karena adanya kesamaan 'illah.

c. Ijtihad istislähi, yaitu ijtihad terhadap masalah yang tidak ditunjuki nash sama sekali secara khusus, maupun tidak adanya nash mengenai masalah yang ada kesamaannya. Dalam masalah yang demikian penetapan hukum dilakukan berdasarkan 'illah untuk kemaslahatan. ${ }^{15}$

Dengan demikian metode ijtihad yang digunakan Majlis Tarjih Muhammadiyah identik dengan metode penaalaran, baik melalui kajian semantik (pola bayānī), penentuan 'illat (pola $t a{ }^{\prime}(\bar{l} i \bar{l})$ maupun pertimbangan kemaslahatan berdasarkan nash umum (pola istislahi) dalam pandangan Muhammad Ma'ruf al-Dawalibi. ${ }^{16}$ Disamping itu, ijtihad yang dilakukan Majlis Tarjih Muhammadiyah merupakan ijtihād jamā'i (ijtihad kolektif dari orangorang Muhammadiyah yang memilki kompetensi mengeluarkan fatwa)

Dari uraian diatas dapat dikemukakan, bahwa istinbat hukum dalam Majelis Tarjih Muhammadiyah menggunakan beberapa metode (manhāj) berdasarkan eksitensi nash dari kasus hukum yang dihadapi antara lain:

a. Masalah yang telah mempunyai nas yang qathi tidak lagi diperdebatkan. ${ }^{17}$

b. Masalah yang mempunyai nas namun masih diperselisishkan, atau saling bertentangan antara satu nas dengan nas lainnya, atau nilai nas itu berbeda, maka Majelis Tarjih Muhammadiyah menempuh cara:

\footnotetext{
${ }^{14}$ Faturrahman Djamil, Metode Ijtihad Majelis Tarjih Muhammadiyah, 161-162.

${ }^{15}$ Faturrahman Djamil, Metode Ijtihad Majelis Tarjih Muhammadiyah, h. 163.

16 Muhammad Ma'ruf al-Dawalibi, al-Madkhāl llā Usul al-Fiqh (Bāirut: Dār al-'llmi li alMalāyīn, 1965), h., 405.

${ }_{17}$ M.Natsir Bakri, Peranan Lajnah Tarjih Muhammadiyah Dalam Pembinaan Hukum Islam di Indonesiaa (Cet. I; Jakarta: CV. Indah Karya, 1985), h. 42-43.
} 
1) Tawaqqūf, yaitu bersikap membiarkan tanpa mengambil keputusan, karena kedua dalil atau lebih yang saling bertentangan itu tidak dapat dikompromikan dan tidak dapat dicarikan alternatif mana yang dianggap paling kuat dalilnya, seperti kasus q ünut dalam salat witir. ${ }^{18}$

2) Tarjīh, yaitu mengambil dalil yang lebih kuat diantara dalil-dalil yang bertentangan. Dalam hal ini ditempuh beberapa metode, yakni:

a) Mendahulukan jarh (cela) daripada $t a^{\prime} d i l$ setelah ada keternagan yang jelas dan sah menurut anggapan syara'.

b) Riwayat orang yang terkenal suka melakukan tadlis dapat diterima bila ia menerangkan bahwa apa yang ia riwayatkan itu bersambung sanadnya, dan tadlisnya itu tidak sampai tercela.

c) Pendapat sahabat tentang perkataan musytarak, pada salah satu artinya wajib diterima.

d) Penafsiran sahabat antara arti kata yang tersurat dengan yang tersirat, arti kata yang tersurat itu yang diutamakan/atau diamalkan. ${ }^{19}$

3) Jam'u, yaitu menjama'atau menggabungkan atau menghimpun antara kedua dalil atau lebih yang saling bertentangan dengan melakukan penyelesaian-penyelesaian. Misalnya, bila ada hadis ahad yang sahih tetapi bertentangan dengan prinsip dasarAjaran Islam, maka kemungkinan hadis itu bersifat insidental atau anjuran yang tidak mengikat secara hukum. ${ }^{20}$

c. Masalah-masalah yang tidak nashnya, padahal dibutuhkan ketentuan hukumnya oleh masyarakat, maka Majlis Tarjih berijtihad mengistinbatkan hukumnya dengan berpedoman kepada prinsip-prinsip ajaran Islam, seperti prinsip kemaslahatan dan menolak kemasfadatan, atau dengan alasan adanya darurat yang dapat menimbulkan ke mudaratan.

Dengan demikian, dalam melakukan istinbāt hukum, Majlis Tarjih Muhammadiyah meletakkan Alquran dan hadis sebagai dasar mutlak. Sedangkan ijtihad dilakukan hanya digunakan jika persoalan yang dihadapi belum disebutkan secara tersurat dalam Alquran dan hadis.

\section{Transformasi Hukum Islam (Fatwa) Majelis Tarjih Muhammadiyah}

Awalnya yang dibahas dan diputuskan oleh Majelis Tarjih Muhammadiyah hanya masalah-masalah keagamaan yang diperselisihkan dengan cara mengambil pendapat yang dianggap kuat dalilnya(tarjīh). Hal itu perlu dilakukan Majelis Tarjih, ketika lembaga ini didirikan karena masalah khïfiyāh sudah begitu meruncing, yang jika tidak diselesaikan, warga

18 Lihat Pimpinan Pusat Muhammadiyah, Himpunan Putusan Majelis Tarjih Muhammadiyah (Cet,III; Yogyakarta: $t$ th.), h., 369.

${ }^{19}$ Lihat Pimpinan Pusat Muhammadiyah, Himpunan Putusan Majelis Tarjih Muhammadiyah h. 301.

${ }^{20}$ Majelis Tarjih Muhammadiyah, " Pembinaan Hukum figh di Bidang Muamalat, " dalam suara Muhammadiyah, Nomor 1,15 juli 1965,h. 31. 
Muhammadiyah sendiri akan mengalami perselisihan yang tajam. ${ }^{21}$

Selaras dengan tugas tersebut Majelis tarjih Muhammadiyah telah melakukan agenda pembahasan muktamar tarjih. Muktamar tarjih yang pertama tahun 1929 di Solo sampai muktamarnya pada tahun 1953,hanya membahas masalah-masalah yang berkaitan dengan ibadah,mulai dari masalah tāhārah, hingga pelaksanaan ibadah haji, ditambah dengan pembahasan jenasah dan wakaf.pada tahun 1954 dan 1955 dibahas masalah "sumber ajaran Islam" dan kegiatan secara global dan masalah-masalah yang berkaitan dengan warga Muhammadiyah secara praktis, seperti batas aurat laki-laki bagi anggota pandu,wanita mngajar laki-laki dan sebaliknya,dan lain-lain. ${ }^{22}$ Mengenai aurat laki-laki yang mengikuti kegiatan pandu Muhammadiyah berpendapat bahwa celana yang digunakan hendaknya menutupi aurat, yaitu menutupi paha sampai lutut,dengan menggunakan hadis yang diriwayatkan oleh Bukhari dari Ibn Abbas dan A'isyah sebagai dasar putusannya. ${ }^{23}$ Sedangkan hukum laki-laki mengajar wanita atau sebaliknya, menurut Muhammadiyah, adalah mubah, dengan menggunakan hadis yang diriwayatkan oleh Bukhari dari abu Sa'id alKhudri sebagai dasar putusannya. ${ }^{24}$

Pada tahun 1960 Muktamar tarjih baru mengadakan pembahasan mengenai masalah pembatasan kelahiran, perburuhan dan hak milik, namun tidak menghasilkan keputusan. Mulai tahun 1968 hingga yang terakhir 1989 baru di bahas dan ditetapkan hukum masalah-masalah muamalah kontemporer. ${ }^{25}$ Dalam Muktamar Tarjih tahun 1968 di Sidoarjo dibahas masalah-masalah bunga bank, keluarga berencana, calo, dan lotto dan sebagainya. Pada tahun 1972 agenda permasalahan yang dibahas adalah asuransi,namun muktamar tersebut tidak menghasilkan keputusan tentang asuransi. ${ }^{26}$ Muktamar Tarjih di Garut tahun 1976 membahas masalah pengelolaan dan pendayagunaan harta dalam Islam ( al-amwāl fi al-Islām) dan etika wanita Islam (adāb al-mar'ati fi al-Islām) sebagai pelaksanaan amanat muktamar tarjih di Wiradesa dan Garut. Kemudian pada tahun 1980 di Klaten, muktamar tarjih membahas masalah bayi tabung dan pencangkokan organ tubuh manusia, dan pada tahun 1989 di Malang muktamar Tarjjih membahas masalah aborsi,perkawinan antar agama, asuransi dan lain-lain. ${ }^{27}$

Dalam perlamkembangan transformasi hukum Islam melalui Majelis Tarjih Muhammadiyah semakin menggeliat dalam merespon berbagai masalah kontemporer selaras dengan kemajuan ilmu pengetahuan dan teknologi. Berikut dikemukakan contoh transformasi hukum Islam (fatwa) diantaranya;

${ }^{21}$ Asmnui Abdul Rahman, et al., Majelis Tarjih Muhammadiyah (Yogyakarta: Lembaga Research dan Survey IAIN Sunan Kalijaga,1985), h. 23

${ }^{22}$ Fathurrahman Djamil, Metode Ijtihad Majelis Tarjih Muhammadiyah., h. 65.

${ }^{23}$ Lihat PP . Muhammadiyah, Himpunan Putusan Majelis Tarjih Muhammadiyah., h. 283-284.

${ }^{24}$ Lihat PP . Muhammadiyah, Himpunan Putusan Majelis Tarjih Muhammadiyah.,, h. 288-289.

${ }^{25}$ Lihat PP . Muhammadiyah, Himpunan Putusan Majelis Tarjih Muhammadiyah., h. 364.

${ }^{26}$ Fathurrahman Djamil, Metode Ijtihad Majelis Tarjih Muhammadiyah ., h. 66.

${ }^{27}$ Lihat PP . Muhammadiyah, Himpunan Putusan Majelis Tarjih Muhammadiyah., h. 369. 


\section{Keluarga Berencana}

Gerakan keluarga berencana digalakkan oleh pemerintah Indonesiaa berkaitan dengan keadaan penduduk Indonesiaa khususnya dan penduduk dunia pada umumnya.Ketika prorgram keluarga berencana pertama kali dicanangkan di Indonesiaa tingkat pertumbuhan Indonesiaa berkisar antara 2 sampai 2,5\% pertahun.Menurut pengamat kependudukan,sekitar tahun 60-an jumlah penduduk pulau Jawa dan Bali sudah sangat padat rata-rata 50 orang perkilometer persegi.keadaan itu sudah berubah lagi pada tahun 1980, dimana kepadatan penduduk menjadi 690 orang perkilometer persegi. ${ }^{28}$

Untuk memasyarakatkan program keluarga berencana itu, pemerintah Indonesiaa meminta kepada umat Islam (sebagai mayoritas penduduk Indonesiaa), khususnya ulama untuk memberikan fatwa tentang masalah KB. Tampaknya Muhammadiyah melalui Majelis Tarjihnya merupakan lembaga yang pertama kali memberikan fatwa tentang keluarga berencana kepada umat Islam di Indonesiaa. Hal ini dibuktikan dengan telah dikeluarkannya fatwa tentang KB pada tahun 1968. Kemudian pada tahun 1971 dibahas lagi oleh 11 ulama terkemuka pada tahun 1983 MUI mengadakan pembahasan lebih lanjut. ${ }^{29}$

Keyakinan umat Islam Indonesia, bahwa Islam menganjurkan untuk memperbanyak keturunan,ternyata diterima oleh Muhammadiyah,dengan pemahaman "kontekstual". Menurut Majelis Tarjih Muhammadiyah, hadis yang menganjurkan memperbanyak keturunan itu harus dipahami sebagai anjuran untuk umat Islam sebagai individu, sehingga setiap individu masih dapat mempertimbangkan situasinya, apakah pada ada kemampuan untuk melaksanakan anjuran tersebut ataukah tidak. ${ }^{30}$

Penjelasan tersebut mengisyaratkan bahwa Majelis Tarjih Muhammadiyah dalam memahami hadis tentang urusan keduniaan menggunakan penalaran lebih dari Majelis Tarjuh setidaknya dalam memahami hadis ini telah melakukan kontekstualisasi ajaran dasar Islam. Anjuran nabi tersebut harus dilihat dari kondisi umat Islam dimasa nabi, sehingga hadis itu dimaksudkan untuk memperkuat barisan umat Islam yang saat itu masih sedikit jumlahnya. ${ }^{31}$ Namun demikian Majelis Tarjih tetap berpendapat bahwa sekarangpun masih diperlukan barisan umat Islam yang banyak hal ini sejalan dengan kerangka berfikir kuantitatif.

Dalam perkembangan kerangka berpikir kuantitatif diganti dengan kerangka berpikir kualitatif, bahwa umat Islam tidak dituntut untuk memproduksi keturunan sebanyak-banyaknya melainkan dituntut untuk membina dan meningkatkan kualitas keturunan yang telah ada. Terhadap kerangka berpikir ini Majelis Tarjih Muhammadiyah menyatakan, bahwa

${ }^{28}$ Masjfuk Zuhdi, Masāil fiqhiyah ( Cet.X; Jakarta: PT Toko Gunung Agung, 1997), h. 56.

${ }^{29}$ Lihat Atho' Mudzhar, Fatwas of the Council of Indonesiaa Ulama, A Study of Islamic legal Thought in Indonesiaa 1975-1988, dalam H. Fathurrahman Djamil , Metode Ijtihad Majelis Tarjih Muhammadiyah., h. 82

${ }^{30}$ Lihat PP. Muhammadiyah, Himpunan Putusan Majelis Tarjih Muhammadiyah ., h. 309.

${ }^{31}$ PP. Muhammadiyah, Membina Keluarga Sejahtera (Yogyakarta; PT Persatuan,t.th.), h. 44. 
disamping isyarat Alquran dan hadis tentang anjuran untuk memperoleh keturunan,namun jangan dilupakan bahwa dalam Alquran dan hadis juga ada isyarat pentingnya peningkatak kualitas umat Islam.Namun demikian pada akhirnya Muhammadiyah berkesimpulan bahwa usaha untuk mengurangi jumlah anak termasuk perbuatan yang dilarang oleh Islam.

Konsekuensi logisnya, Majelis Tarjih berpendapat bahwa pencegahan kehamilan adalah haram. Bahkan penjarakan atau pengaturan kelahiran pun pada dasarnya tidak dibenarkan. Walaupun begitu yang menarik dari putusan majelis Tarjih Muhammadiyah yang masih membolehkan Keluarga Berencana dalam kondisi darurat, antara lain:

a. Menghawatirkan keselamatan jiwa atau kesehatan ibu karena mengandung atau melahirkan, bila hal ini diketahui dengan pengalaman atau keterangan dokter yang dapat dipercaya.

b. Menghawatirkan keselamatan agama, akibat faktor-faktor kesempitan kehidupan, seperti kekhawatiran akan terseret menerima hal-hal yang haram, atau menjalankan/melanggar larangan agama,karena didorong oleh kepentingan anak-anak.

c. Menghawatirkan kesehatan atau pendidikan anak-anak bila jarak kelahiran terlalu dekat. ${ }^{32}$

Tampaknya Muhammadiyah hanya membolehkan suami istri untuk mengatur jarak kelahiran, dengan alasan adanya kekuatiran terhadap keselamatan ibu dan anak jika jarak kelahiran terlalu dekat. Sedangkan usaha memperkecil keturunan, tanpa adanya kekuatiran,tidak dibenarkan. Karena itulah Muhammadiyah cenderung menggunakan istilah "keluarga sejahtera" daripada "keluarga berencana."

Muhammadiyah hanya memberi petunjuk secara umum melalui pernyataannya, bahwa keluarga berencana harus dilakukan dengan cara-cara yang benar, disetujui oleh suami isteri dan tidak membahayakan bagi yang bersangkutan. ${ }^{33}$ Sehubungan dengan hal ini, Muhammadiyah mengajukan beberapa alternatif pengaturan kehamilan,antara lain: (1) azal (coitus interuptus), (2) Menggunakan IUD, (30 Sterilisasi, dan (40 abortus. Dari keempat alternatif tersebut Majelis Tarjih Muhammdiyah memboleh alternatif pertama dan kedua (azal dan penggunaan alat kontrasepsi termasuk alat-alat kontrasepsi dalam rahim atau (AKDR). Sedangkan sterilisasi diharapkan secara mutlak. Adapun abortus hanya dibenarkan berdasarkan indikasi medis.

Dengan demikian dalam menetapkan hukum keluarga berencana beserta teknis pelaksanaannya, Majelis Tarjih Muhammadiyah menggunakan metode istinbāt bì al-maslahā atau istihsān bi al-durūrāh. Tegasnya bahwa Majelis Tarjih Muhammadiyah telah menggunakan pendekatan maslahāh yang merupakan unsur utama dalam maqāsìd al-syarì'ah dalam menyelesaikan masalah keluarga berencana.

\footnotetext{
32 PP Muhammadiyah, Himpunan Putusan Majelis Tarjih Muhammadiya, h 309-310

${ }^{33}$ PP Muhammadiyah, Membina Keluarga Sejahtera, h 49.
} 


\section{Bunga Bank}

Bank merupakan lembaga keuangan yang usuha pokoknya adalah memberikan kredit dan jasa-jasa dalam lalu lintas pembayaran serta peredaran uang.untuk melaksanakan fungsinya,bank "membeli uang" dari masyarakat pemilik dana dengan harga tertentu yang disebut "bunga kredit." Sebaliknya bank akan "menjual uang " dengan cara memimjamkannya kepada pihak lain dengan harga tertentu pula,sebaliknya disebut "bunga debit." Jadi, keadaan dan fungsi uang tidak berbeda dengan barang atau alat-alat produksi lainnya. Kelebihan uang dibanding alat-alat produksi lainnya adalah uang berfungsi juga sebagai alat tukar yang mempunyai sifat likuiditas dan merupakan ukuran nilai barang. ${ }^{34}$

Namun di sisi lain pemilik modal dan bank melakukan tindakan transaksi utang piutang. Dalam hal ini pembebanan tambahan terhadap orang yang berutang yang mengarah kepada riba. Padahal riba telah di haramkan dalam Alquran. Karena itulah Muhammadiyah telah membahas bunga bank khususnya dan lembaga keuangan umumnya. Dalam hal ini menurut, Muhammadiyah bahwa hakikat riba yang dilarang dalam Alquran adalah riba yang mengarah kepada pemerasan terhadap debitur. Hal ini dapat dilihat dalam konsideran putusan Majelis Tarjih tentang bunga Bank, "bahwa nashnash Alquran dan sunnah tentang haramnya riba mengesankan adanya illat terjadinya penghisapan oleh pihak yang kuat terhadap yang lemah." 35

Tampaknya Muhammadiyah bermaksud menetapkan kehalalan bunga bank milik negara, tetapi tidak menyatakannya dan lebih bersikap hati-hati buktinya ketika menjelaskan putusannya tentang bunga bank milik negara itu musytabihat. Majelis Tarjih Muhammadiyah menegaskan, bahwa jika setelah dikaji dan diselidiki dengan seksama, melalui prosedur tertentu yang berlaku kemudian berdasarkan ijtihad mereka telah dapat ditentukan salah satu diantara dua hukum yang semula diragukan itu,maka perkara yang musytabihat itu bisa menjadi tidak lagi demikian. ${ }^{36}$ Jadi, Muhammadiyah cenderung menghalalkan bunga bank milik negara. Dalam kaitan ini Muhammadiyah menggunakan tolok ukur kemaslahatan yang menjadi maqasid al-syari'ah. Jelasnya, kepentingan dan kebutuhan umat Islam tidak boleh diabaikan.

Dalam kaitan ini tampaknya Muhammadiyah menggunakan beberapa metode secara bersamaaan, seperti qiyas, istishab dan maslahat.

\section{KESIMPULAN}

Berdasarkan uraian sebelumnya, dapat disimpulkan yaitu:

1 Manhaj yang digunakan Majelis Tarjih Muhammadiyah dalam melakukan ijtihad bervariasi jika dikaitkan dengan substansi masalah yaitu;

${ }^{34}$ Syafruddin Prawiranegara, Uang dan Bank Ditinjau dari segi Ekonomi dan Agama (Jakarta: Pustaka Antara, t,th.) h.-8-9.

35 PP.Muhammadiyah, Himpunan Putusan Majelis Tarjih, h. 304.

36 PP Muhammadiyah, Himpunan Putusan Majelis Tarjih., h. 307. Seiring perjalanan waktu, Muhammadiyah pada Sabtu, 3 April 2010 mengeluarkan fatwa keharaman bunga bank. 
a. Apabila masalah telah ada nashnya, namun demikian nash tersebut masih diperdebatkan, maka digunakan pendekatan tawaqquf atau tarjih serta jam'u.

b. Apabilah masalah tersebut sangat dibutuhkan masyarakat, akan tetapi tidak ada nashnya, maka dilakukan ijtihad dengan cara bayani, qiyasi, istislahi dan sadd al-zari'ah dengan tetap mengacu kepada prinsip jalbu masalaih wa daf'u mafasid.

2. Majelis Tarjih Muhammadiyah telah memberikan kontribusi terhadap transformasi hukum Islam di Indonesiaa dalam bentuk fatwa seperti dalam dunia medis, misalnya; KB. Dalam bidang ekonomi dan keuangan, misalnya; bunga bank.

\section{DAFTAR PUSTAKA}

Abdul, Mannan. Reformasi Hukum Islam di Indonesia. Cet. I; PT. Raja Grafindo. Persada, 2006.

al-Dawalibi, Muhammad Ma'ruf. al-Madkhal lla Usul al-Fiqh. Bayrut: Dar al-`llmi li al-Malayin, 1965.

Asmnui Abdul Rahman, et al., Majelis Tarjih Muhammadiyah (Yogyakarta: Lembaga Research dan Survey IAIN Sunan Kalijaga, 1985.

Bakri, M. Natsir. Peranan Lajnah Tarjih Muhammadiyah Dalam Pembinaan Hukum Islam di Indonesiaa. Cet. I; Jakarta: CV. Inda h Karya, 1985.

Dahlan, Abdul Azis. Ensiklopedi Hukum Islam, Jilid I. Cet. V; PT. Ichtiat Baru Van Houve, 2001.

Djamil, Faturrahman. Metode Ijtihad Majelis Tarjih Muhammadiyah.Cet. 1; Jakarta: Logos Publishing House, 1995.

Fuad, Mahsun. Hukum Islam Indonesiaa dari Nalar Partisipatoris Hingga Emansipatoris. Cet. 1; Yogyakarta: LKIS, 2005.

Kamal, Mustafa et al.. Muhammadiyah Sebagai Gerakan Islam (Yogyakarta: Persatuan, 1988.

Majelis Tarjih Muhammadiyah, "Pembinaan Hukum figh di Bidang Muamalat, “dalam suara Muhammadiyah, Nomor 1,15 julu 1965,

Mubarak, Jaih. Metodologi Ijtihd Hukum Islam (Yogyakarta: UII Press, 2002

Muzhar, Atha'. Fatwas of the Council of Indonesiaa Ulama, A Study of Islamic legal Thought in Indonesiaa 1975-1988.

Nasution, Harun. Islam Ditinjau dari Berbagai Aspeknya, Jilid I (Cet. V; Jakarta; UI Press, 1985.

Noer, Deliar. Gerakan Islam Modern di Indonesiaa 1990-1942.Jakarta: LP3ES, 1982.

Pimpinan Pusat Muhammadiyah, Himpunan Putusan Majelis Tarjih Muhammadiyah. Cet. III; Yogyakarta: [t.p.],[t.h].

Praja, Juhaya S. Filsafat Hukum Islam.Cet. I; Bandung; Piara, 1993. 
Prawiranegara, Syafruddin. Uang dan bank Ditinjau dari segi Ekonomi dan Agama Jakarta: Pustaka Antara, t,th.

Schachat, Yoseph. An Introduction to Ismaic Law. Oxford: Oxford University Press, 1964.

Syarifuddin, Amir. Meretas Ijtihad; Isi-Isu Penting Hukum Islam Kontemporer di Indonesiaa. Cet. I; Jakarta: Ciputat Press, 2002.

Tamimi, Djindar. "Tajdid: Ideologi dan Chittah Perjuangan Muhammadiyah," Buletin Suara Muhammadiyah, No. 91, 16 September 1969.

Zuhdi, Masjfuk Masail fiqhiyah. Cet.X; Jakarta: PT TOKO Gunung Agung,1997. 